\title{
Within but without: human rights and access to HIV prevention and treatment for internal migrants Katherine Wiltenburg Todrys ${ }^{1}$ and Joseph J Amon*2
}

\author{
Address: ${ }^{1}$ Health and Human Rights Division, Human Rights Watch, London, UK and ${ }^{2}$ Health and Human Rights Division, Human Rights Watch, \\ NY, NY, USA \\ Email: Katherine Wiltenburg Todrys - todrysk@hrw.org; Joseph J Amon* - amonj@hrw.org \\ * Corresponding author
}

Published: 19 November 2009

Globalization and Health 2009, 5:17 doi:10.1186/1744-8603-5-17
Received: 15 July 2009

Accepted: 19 November 2009

This article is available from: http://www.globalizationandhealth.com/content/5/1/17

(C) 2009 Todrys and Amon; licensee BioMed Central Ltd.

This is an Open Access article distributed under the terms of the Creative Commons Attribution License (http://creativecommons.org/licenses/by/2.0), which permits unrestricted use, distribution, and reproduction in any medium, provided the original work is properly cited.

\begin{abstract}
Worldwide, far more people migrate within than across borders, and although internal migrants do not risk a loss of citizenship, they frequently confront significant social, financial and health consequences, as well as a loss of rights. The recent global financial crisis has exacerbated the vulnerability internal migrants face in realizing their rights to health care generally and to antiretroviral therapy in particular. For example, in countries such as China and Russia, internal migrants who lack official residence status are often ineligible to receive public health services and may be increasingly unable to afford private care. In India, internal migrants face substantial logistical, cultural and linguistic barriers to HIV prevention and care, and have difficulty accessing treatment when returning to poorly served rural areas. Resulting interruptions in HIV services may lead to a wide range of negative consequences, including: individual vulnerability to infection and risk of death; an undermining of state efforts to curb the HIV epidemic and provide universal access to treatment; and the emergence of drug-resistant disease strains. International human rights law guarantees individuals lawfully within a territory the right to free movement within the borders of that state. This guarantee, combined with the right to the highest attainable standard of health set out in international human rights treaties, and the fundamental principle of non-discrimination, creates a duty on states to provide a core minimum of health care services to internal migrants on a non-discriminatory basis. Targeted HIV prevention programs and the elimination of restrictive residence-based eligibility criteria for access to health services are necessary to ensure that internal migrants are able to realize their equal rights to HIV prevention and treatment.
\end{abstract}

\section{Introduction}

Worldwide, far more people migrate within their country than out of it [1]. Internal migrants--as opposed to international migrants--are those individuals who change residence from one civil division to another within their country of origin. Reasons for migration are varied, but typically stem from social, political, or financial causes, or natural disaster. Urbanization and increased manufactur- ing in East and Southeast Asia have led to circular ruralurban migration in unprecedented numbers in Indonesia, Vietnam, and Cambodia, and to increased rural-rural and rural-urban migration in India [1]. In some cases, the lifting of restrictions on movement--as in South Africa in the post-apartheid era--have led to increased internal migration [1], and migration within countries in Eastern Europe and the Commonwealth of Independent States since the 
fall of the Soviet Union has been significant [2]. Intrametropolitan migration has become increasingly common in Latin America as well [1].

The global financial crisis has seriously affected spending on HIV/AIDS services, and a March 2009 survey by the World Bank, the Joint United Nations Programme on HIV/AIDS (UNAIDS), and the World Health Organization (WHO) found that some countries are already facing drug shortages and other disruptions in HIV/AIDS treatment [3]. The report predicted that the crisis would further impact prevention and treatment programs, leading to increased illness, death, and the development of drug resistance. The financial crisis has particularly thrown into relief the plight of internal migrants as it has exacerbated health and social inequalities $[3,4]$. In declining markets, migrant workers are often the first to lose their jobs: By February 2009 in China, approximately 20 million migrant workers had been laid off or were unable to find work [5]. With fragile social support networks, the healthrelated consequences of unemployment for this population may be dire; returning to often rural and impoverished origins or seeking work in new locations may be equally difficult.

International human rights law guarantees individuals lawfully within a territory the right to free movement within the borders of that state [6], a commitment legally binding on all parties to the International Covenant on Civil and Political Rights (ICCPR) [7]. The Human Rights Committee, the ICCPR's monitoring body, has noted that liberty of movement is an "indispensable condition for the free development of a person." [8] The International Convention on the Elimination of All Forms of Racial Discrimination also supports the right to freedom of movement within a state [9]. But while such freedom of movement is assured by international law, it is not always respected in practice by states, as countries put restrictions on movement and limit services available to unofficial internal migrants.

Already marginalized and subject to stigma as a result of their migration status [10], migrants with HIV/AIDS are doubly stigmatized and are subject to neglect and exploitation [11]. Gaps in internal migrants' access to HIV/AIDS services--either as a result of official restrictions or logistical, cultural and linguistic barriers--have significant consequences: individuals are less able to access care and are increasingly vulnerable to infection and death, states are less able to realize the goals of universal access to treatment and reduction of the AIDS epidemic, and the public health community may face the emergence of drug-resistant strains resulting from interruptions in treatment [12]. This article describes some of the barriers to access to HIV/ AIDS-related services faced by internal migrants when they move from their place of origin, highlighting three countries--China, Russia, and India--that have internal migration restrictions, and logistical, linguistic and cultural barriers to HIV/AIDS prevention and treatment. To successfully achieve global goals for reducing the burden of HIV and providing universal access to prevention and care, states must recognize the rights of internal migrants and their own obligations to eliminate barriers to care.

\section{Barriers to HIVIAIDS prevention and treatment facing internal migrants: China, Russia, and India The People's Republic of China}

As a result of economic reforms, a surplus of rural labor and desperate rural poverty, internal migration has drastically increased in China in recent years. As of December $31,2008,140.4$ million internal migrants in China worked outside their home village or township [13], an increase from only two million internal migrant workers two decades earlier [14]. Internal migrants make up a sizeable percentage of the urban population and workforce [15].

Through the system of hukou, the People's Republic of China requires the registration of every Chinese resident with the local authorities. Although the Chinese government has announced plans for its elimination [16], hukou allows individuals to live and work only where they are officially permitted [15], with one place of permanent hukou registration. Hukou status is inherited, so that children of rural-to-urban migrants are, like their parents, not registered urban residents [17]. Procedures to obtain temporary residence can be time-consuming, expensive, and difficult [18]. Only an estimated $40 \%$ of China's internal migrants typically obtain temporary or permanent permits [14].

While urban permit-holding residents in China have long been entitled to state-sponsored social welfare benefits including retirement pensions, food, education, and medical care, internal migrants still registered in their rural household of origin are denied such benefits [19]. Individuals without hukou are unable to access basic public services such as education [20] and health care [21], and therefore are forced to pay all costs $[15,21]$. Amnesty International has noted that the vast majority of internal migrants in China cannot afford insurance schemes and rarely visit doctors or hospitals [18]. Human Rights Watch has documented widespread lack of insurance coverage for migrant construction workers, despite government guarantees of medical and accident insurance [19]. Furthermore, lack of health care coverage for sick migrants has, in the past, been compounded by additional, harsh consequences: For example, internal migrant workers have been returned to their home province under armed guard after being found to be HIV positive [22]. Though 
China announced the abolition of such "custody and repatriation" in 2003 [23], recent reports suggest that similar practices of detention and removal purportedly for health reasons are still practiced, particularly during periods of heightened political concern [24].

A range of studies have documented the disproportionately high prevalence of HIV among internal migrants: Multi-city HIV surveillance data between 1995 and 2000 revealed that over two-thirds of the HIV cases were found among rural-to-urban migrants. In 2000, 85.4\% of Beijing's and $74.4 \%$ of Shanghai's new HIV infections occurred among migrants $[25,26]$. Despite such high prevalence, and nationwide prevention campaigns in recent years, as well as studies calling urgently for HIV prevention programs addressing the particular circumstances of migrants [27], internal migrants in China have disproportionately low access to HIV/AIDS-related information $[18,26,28]$. United Nations reports have also remarked on the special vulnerability and difficulty of reaching with prevention programs the children of migrants, who lack access to the formal Chinese schooling system [29].

HIV-positive internal migrants' access to treatment remains extremely limited, confounded in part by the effects of the hukou system. Prior to 2003, ART was only available to the wealthy elite, as hospitals and clinics passed along to all patients the cost of HIV/AIDS examinations, tests, hospitalizations, treatment for opportunistic infections and ART treatment [22]. In 2003, the Chinese government announced a national HIV/AIDS treatment program--free to rural residents and poor urban residents--funded by national and provincial authorities [30]. However, despite such broad policy statements, universal HIV/AIDS treatment is far from a reality among the general population: In 2007, UNAIDS estimated that 190,000 people living with HIV were unable to access urgently needed ART in China, representing $81 \%$ of those in need [31]. Even when free treatment is ostensibly offered, delays in diagnosis and referral can create significant costs for the patient prior to the availability of free treatment, thus particularly disadvantaging migrants, who are not entitled to free basic health care [32].

The negative health consequences of the restrictive hukou system and related gaps in HIV/AIDS prevention and treatment for internal migrants have been exacerbated by the recent crisis in the world financial markets. For example, the loss of jobs in the export manufacturing sector, such as in the Pearl River Delta region, is anticipated to increase the number of migrant women working in the sex industry [33]. As unemployed internal migrants return to rural areas there is a potential for increased HIV transmission, as well as a risk that inadequate and weakened rural health systems will become overburdened [30]. Recogniz- ing the current disparity in health care access, and widespread dissatisfaction, the Chinese government has recently announced plans for significant investment in basic health care services [35].

\section{The Russian Federation}

Vestiges of an internal registration system also plague access to health care for internal migrants in Russia. In the former Soviet Union, propiska--a residence permit stamp on internal Soviet passports--strictly limited movement and residence. Although propiska was officially abolished by the federal government in the 1990s, local and regional governments retain restrictive systems of registration for both temporary visitors and residents [36]. While reliable statistics are unavailable, government officials have estimated that over a million unregistered individuals may live in Moscow alone [37].

In recent years, legislative and other changes have led to the simplification and relaxation of some registration requirements [36-38]. Federal law and policy provide for freedom of movement and, while requiring registration [39], envision it as a non-discretionary, notice-based system open to all. However, in practice, registration is cumbersome and expensive, and lack of registration status may have serious official or unofficial consequences for internal migrants. Instances of unregistered migrants unable to legally marry, vote, send their children to school, and receive public assistance, have all been reported [36]. Indeed, individuals who are legally in the country but lack local registration have also reportedly faced such harsh consequences as detention, police abuses or deportation $[36,40,41]$.

While the Russian government is constitutionally required to provide free medical care to all citizens $[42,43]$, regional authorities, responsible for the organization and financing of medical programs in their territories, regulate the conditions for access to medical care. Federally funded HIV treatment is officially provided free of charge to citizens $[44,45]$, but in practice major challenges exist in access to free health care generally as a result of inadequate federal and regional funding [46]. UNAIDS estimated in 2007 that 159,000 individuals needing ART were not receiving it, as only $16 \%$ of those requiring ART had access to treatment [47]. Internal migrants especially face barriers, as registration is a precondition for entitlement to many free health services $[48,49]$.

Human Rights Watch research has documented that internal migrants without registration are often denied both short-term (for purposes of Prevention of Mother to Child Transmission) and long-term antiretroviral treatment [50]. In Moscow, individuals must produce temporary 
registration and an official certificate of HIV-status in order to obtain ART at the Moscow AIDS Center. While unregistered international migrants may, in some cases, receive antiretrovirals for free, a non-resident requiring antiretrovirals will typically be directed to his or her city of origin to receive the treatment. Despite these barriers to accessing care, currently applicable Russian federal law on HIV/AIDS does not specifically address the particular challenges involved in providing HIV prevention, care and treatment services to migrants [44].

There is some preliminary indication that the global financial crisis may in fact lead to an increased movement into Russian cities, where the remaining registration systems prevent internal migrants from accessing some social services: According to the head of the Moscow Directorate of Internal Affairs, increasing unemployment as a result of the global financial crisis in Russia has lead to an influx of migrants from regions surrounding Moscow into the city in search of work. In addition to facing the restrictions detailed above, these internal migrants have been blamed for an increase in crime [51], and have encountered significant hostility and attacks [52].

\section{Republic of India}

India, like China and Russia, has high rates of internal migration--both rural-rural and increasingly rural-urban [1]--complicated by diverse cultural and linguistic traditions. An estimated 258 million adults in India are migrants [53]. While poverty and internal mobility itself does not lead to HIV transmission, unsafe sex and a change in sexual networks may $[54,55]$. The World Bank has characterized migration and mobility, particularly for work purposes, as one of the major risk factors for HIV in India [56]. The national government's response to HIV/ AIDS has recognized the key role that migrants have played in the on-going epidemic [57]. While the correlation between migration status and HIV infection in India may have been weakening in recent years [55], rising unemployment as a result of the financial crisis and the existence of return migration may have the potential to increase transmission [58].

Approximately 2.4 million people were living with HIV/ AIDS in India in 2008 [59]. HIV prevention is seriously hindered by the low awareness of the disease among internal migrants, particularly from rural areas [56,57]. UNAIDS India representatives have called for awareness campaigns specifically targeting the sending areas for internal migrants [54], however HIV prevention activities can be hindered by the mobile nature of this population [60], language, and cultural barriers [53].

Significant HIV/AIDS treatment gaps exist for all groups throughout the country, but migrants also face particular challenges in accessing health care $[59,61]$. Health care is administered on a state-by-state basis in India, and in some states significant uncertainty exists among government officials as to whether state authorities are responsible for social welfare services to temporarily resident workers and their families [62]. Furthermore, internal migrants are often unable to use the government-issued "ration cards" outside their local home authority in order to access social services [63], and migrants may face significant logistical challenges and delays in procuring a new ration card [64]. Absent a ration card, it can be difficult to access even programs designed to provide health care to the poor, as some such services specifically target ration card holders [65]. Indeed, some local authorities reportedly refuse to provide ART entirely to individuals without ration cards [66]. In one area with extensive seasonal outmigration, a study concluded that internal migrants reported poorer health-seeking behavior than their nonmigrant counterparts, a difference attributed to ignorance of behavioral risk factors, lack of knowledge of health facilities, and cultural and linguistic barriers [55].

Though not as severe as in some countries worldwide, the current global financial crisis has slowed economic growth in India and threatened to exacerbate preexisting levels of internal inequality [67]. Internal migrants are particularly vulnerable to increased unemployment and poverty, and the process of reverse migration has already begun [68]. The Governor of the Reserve Bank of India noted in February 2009 that social safety net programs in rural areas could help to mitigate the impact of the crisis for migrant workers who return home [69]; however, ART coverage throughout the country is plagued by broad gaps and failures and interruptions in treatment must be expected.

\section{International law}

International human rights law guarantees individuals lawfully within a territory the right to free movement within the borders of that state [6], a commitment legally binding on all parties to the International Covenant on Civil and Political Rights [7]. International law also provides for the basic right to the highest attainable standard of health. This right, along with the principle of non-discrimination, implies a clear right to access a core minimum set of health services for migrants who move within their own state, including ART, without discrimination on the basis of social origin.

\section{Right to highest attainable standard of health}

All individuals have the right to enjoy the highest attainable standard of health, a right which has been enshrined in international and regional treaties. According to the Universal Declaration of Human Rights (UDHR), " [e]veryone has the right to a standard of living adequate 
for the health and well-being of himself and of his family, including food, clothing, housing and medical care and necessary social services." [6] The International Covenant on Economic, Social and Cultural Rights also guarantees the right of everyone to the highest attainable standard of health, and requires states parties to take steps individually and through international cooperation to progressively realize this right via the prevention, treatment, and control of epidemic diseases and the creation of conditions to assure medical service and attention to all [70]. "Progressive realization" demands of states parties a "specific and continuing obligation to move as expeditiously and effectively as possible towards the full realization of [the right]." [71] According to the WHO, " [w]hen considering the level of implementation of this right in a particular State, the availability of resources at that time and the development context are taken into account. Nonetheless, no State can justify a failure to respect its obligations because of a lack of resources." [72] The concept of available resources is intended to include available assistance from the international community [73].

The right to health is further guaranteed by a number of other international human rights treaties and commitments. The Convention on the Rights of the Child binds states to "recognize the right of the child to the enjoyment of the highest attainable standard of health and to facilities for the treatment of illness and rehabilitation of health. States Parties shall strive to ensure that no child is deprived of his or her right of access to such health care services." [74] The right to health is also protected under the International Convention on the Elimination of All Forms of Racial Discrimination [9], the Convention on the Elimination of All Forms of Discrimination Against Women [75], the International Convention on the Protection of the Rights of All Migrant Workers and Members of Their Families [76], and the Convention on the Rights of Persons with Disabilities [77]. Additionally, governments committed in the 2001 Declaration of Commitment on HIV/AIDS to "promote and protect all human rights and fundamental freedoms, including the right to the highest attainable standard of physical and mental health" and "in an urgent manner make every effort to: provide progressively and in a sustainable manner, the highest attainable standard of treatment for HIV/AIDS, including the prevention and treatment of opportunistic infections, and effective use of quality-controlled anti-retroviral therapy in a careful and monitored manner to improve adherence and effectiveness and reduce the risk of developing resistance" [78].

To be consistent with the right to health, the health resources provided should have the characteristics of respect for medical ethics, cultural appropriateness, and respect for confidentiality. Indeed, " [a]ll health facilities, goods and services must be... respectful of the culture of individuals, minorities, peoples and communities, sensitive to gender and life-cycle requirements, as well as being designed to respect confidentiality and improve the health status of those concerned" [71].

\section{Principles of equality and non-discrimination}

International law also establishes the fundamental principles of non-discrimination and equality. The Universal Declaration of Human Rights proclaims that " [e]veryone is entitled to all the rights and freedoms set forth in this Declaration, without distinction of any kind, such as race, colour, sex, language, religion, political or other opinion, national or social origin, property, birth or other status". [6] Additionally, under that Declaration, " [a]ll are equal before the law and are entitled without any discrimination to equal protection of the law" [6]. The ICCPR echoes the UDHR's proclamations against discrimination, binding states party to recognize the rights it guarantees without distinction of any kind, including based on race, colour, sex, language, religion, political or other opinion, national or social origin, property, birth or other status [7]. The ICCPR also notes the equality of all persons before the law and requires that the law prohibit discrimination and guarantee equal protection against discrimination on any ground, including the above-noted ones [7]. The Human Rights Committee, the ICCPR's monitoring body, has determined non-discrimination, equality before the law, and equal protection, to be basic principles in the protection of human rights [79]. Indeed, the Human Rights Committee, the ICCPR's monitoring body, has noted that states must eliminate all discrimination and indeed in some cases may need to take affirmative steps to realize the value of that guarantee [79].

\section{Non-discrimination in health}

Numerous international and regional bodies have, considering the abovementioned right to the highest attainable standard of health and principle of nondiscrimination, addressed specifically the prohibition on discrimination in health services. According to the Economic, Social and Cultural Rights Committee, the Covenant on Economic, Social and Cultural Rights' monitoring body, States must guarantee certain core obligations as part of the right to health, including ensuring non-discriminatory access to health facilities, particularly for vulnerable or marginalized groups; providing essential drugs; ensuring equitable distribution of all health facilities, goods and services; adopting and implementing a national public health strategy and plan of action with clear benchmarks and deadlines; and taking measures to prevent, treat and control epidemic and endemic diseases [71]. While the Committee notes the progressive nature of the right to health, it also points to the fact that states must immediately take steps to realize the right to health, and 
must immediately guarantee the exercise of the right without discrimination of any kind [71].

The right to health is thus centrally linked to the right to non-discrimination. Indeed, the Committee has noted that "the Covenant proscribes any discrimination in access to health care and underlying determinants of health, as well as to means and entitlements for their procurement, on the grounds of race, colour, sex, language, religion, political or other opinion, national or social origin, property, birth, physical or mental disability, health status (including HIV/AIDS), sexual orientation and civil, political, social or other status, which has the intention or effect of nullifying or impairing the equal enjoyment or exercise of the right to health...With respect to the right to health, equality of access to health care and health services has to be emphasized. States have a special obligation to provide those who do not have sufficient means with the necessary health insurance and health-care facilities, and to prevent any discrimination on internationally prohibited grounds in the provision of health care and health services, especially with respect to the core obligations of the right to health...." [71].

Discrimination against internal migrants--who are in fact citizens of the state in question--is banned under the Committee's Comments, which explicitly state that the Covenant prohibits discrimination based on "social origin." The ban against discrimination receives further confirmation when the Committee stresses each state's obligation to make health facilities and services accessible to everyone within the state's jurisdiction without discrimination, particularly the most vulnerable, so that health facilities, goods and services are within safe physical reach of "all sections of the population," "especially vulnerable or marginalized groups, such as ethnic minorities and indigenous populations, women, children, adolescents, older persons, persons with disabilities and persons with HIV/AIDS" [71]. Thus, the Committee findings make clear that the Covenant prohibits discrimination against internal migrants in receiving health care, and are an immediate call on all states parties to eliminate discrimination.

The Committee on the Rights of the Child has spoken specifically to the relationship between HIV/AIDS and the rights outlined in that Convention, determining that the right to non-discrimination should be one of "the guiding themes in the consideration of HIV/AIDS at all levels of prevention, treatment, care and support" [80].

\section{Discussion}

In the history of the response to HIV/AIDS, governments have frequently sought to blame culturally different "others"-first, foreigners, and second, minorities, migrants and individuals considered socially "deviant" [81,82]. Internal migrants are often included in more than one of these categories, and have long struggled to gain access to HIV prevention information and treatment. As HIV programs seek to scale-up services and fulfill commitments to provide "universal access" to prevention and care, it continues to be controversial to include migrants among those who are entitled to care [83], and in some cases migrants are subject to treatment including deportation as a result of their very HIV status $[84,85]$. As with international migrants, whose rights are frequently denied, internal migrants' rights are often unrecognized $[1,18,86]$.

China, Russia and India, like many countries worldwide, are rapidly scaling up provision of ART. Between 2004 and 2007, the estimated number of people receiving ART in China rose from 9,000 to 35,000 [31]. In Russia, the estimated number of people receiving ART rose from 3,000 in 2004 to 31,000 in 2007 [47]. In India, the estimated number of people receiving antiretroviral therapy increased from 28,000 in 2004 to 158,000 in 2007 $[59,87]$. But without the implementation of free treatment, the elimination of eligibility restrictions for access to care, an end to restrictions on internal migrants, and targeted programs to facilitate access to HIV prevention info and treatment, universal access goals will fail and internal migrants will continue to face barriers to accessing care.

First, states need to implement free ART for internal migrants on the same terms as local residents. Research has found that user fees constitute the main barrier to ART adherence, and that free care at point of service leads to improved uptake of HIV-related services, especially among the poorest users [88-93]. Lack of access to treatment from government-sponsored health sources also serves to push internal migrants toward self-medication or illegal clinics [94]. Such clinics and self-medication expose internal migrants to a host of health risks, including from counterfeit pharmaceuticals and unproven AIDS 'cures' [95].

States must also work to alleviate the hidden costs of receiving treatment. Research has shown significant additional costs to receiving treatment even for those people entitled to free ART: In India, free ART at government-run centers is complicated by transport costs which may include overnight stays near the clinic (especially given few centers in rural areas), private clinic fees paid after negative experiences with government clinics, the cost of vitamins and nutritious food, lost time waiting in government hospitals, payment for drugs at times of government stock outs, and costs for second-line drugs for individuals who developed resistance to first-line drugs [96]. 
Second, in countries that place formal or informal eligibility restrictions on access to health care, such restrictions based on social origin within different regions of the country need to be immediately eliminated. As noted above, the Economic, Social and Cultural Rights Committee directs that states have an immediate obligation to eliminate discrimination in health care provision, including discrimination based on "social origin." The obligation to ensure HIV/AIDS prevention and treatment to all individuals without discrimination is all the more acute, as antiretroviral medicines used in the prevention and treatment of HIV/AIDS are included as essential medicines in the core minimum of health care services nations have an obligation to provide [71,97]. Some sources, including the UN Special Rapporteur on the Right of Everyone to the Enjoyment of the Highest Attainable Standard of Physical and Mental Health, have argued that essential medicines, as part of the core of the right to health, are subject to immediate realization for the entire population rather than progressive [98].

Third, national governments need to remove restrictions on movement that prevent or delay internal migrants from establishing residence in urban areas. The harsh consequences and rights violations of restrictions on internal migration in some countries can include detention or deportation. Fear of such consequences may lead internal migrants to avoid HIV-related services even when they are available. Human Rights Watch has documented the chilling effect that fear of detention and deportation of foreign-born mothers can have on their Chinese partners' decisions to obtain hukou for their children and enroll them in school [20]. Human Rights Watch has also noted Chinese internal migrants' fear of contact with the official government services out of concern that they will be ejected from their city of residence [19]. In Russia, Human Rights Watch found that " [m]igrants with irregular status are more vulnerable to abuses and less willing to seek assistance from government agencies out of real fears that approaching any official person or body will result in a fine or expulsion" [99].

Finally, creating programs tailored specifically to internal migrants' needs is essential to uptake even of free HIV prevention and treatment services. The experience of free tuberculosis (TB) treatment programs is illustrative both as a model for other health services and in suggesting what targeted programs may be necessary to make even free care truly accessible to internal migrant populations. In many countries, TB treatment is widely provided free of charge by national governments to all individuals regardless of citizenship or residency status [100]. Provision of TB treatment is often more widely available within countries than HIV treatment--in India, for example, in 2006, 634 (100\% coverage) Ministry of Health facilities in the country were providing Directly Observed Treatment, Short-course (DOTS) services for TB treatment [101], whereas in 2007, only 137 sites nationwide were providing ART [59]. Free universal TB treatment can serve as a model for the expansion of free HIV treatment, and existing TB services represent an opportunity for expanding access to HIV prevention, treatment, care and support, particularly in the context of HIV/TB co-infection.

Yet TB treatment for migrants is also a cautionary tale of the barriers that still exist when ostensibly free care is implemented without programs targeted to alleviate internal migrants' particular circumstances. In China, a country with one of the highest TB burdens in the world, the government has worked since at least 1978, and increasingly since 1991 with the initiation of the National TB Control Program, to implement the DOTS program, to increase TB treatment. In 2005 China had established TB coverage over $100 \%$ of the country (though quality concerns remained) [102]. However, migrant status remains a main reason for delays in diagnosis [103]. Indeed, without hukou, migrant workers rarely have access to free TB diagnosis and treatment. Hidden costs arise despite officially free TB treatment and care in China because of doctor recommendations to buy medications to counter side effects of the treatment and the need to visit health care facilities repeatedly. In addition to these costs, and low awareness of treatment options, for migrants, challenges have been reported, as "urban TB control systems tend not to pay enough attention to migrants. They are not required by policies to focus on the needs of migrants and provision of services for them is considered 'extra' work. Many staff have the impression that $\mathrm{TB}$ control for migrants is not important" [103]. Unsurprisingly, TB cure rates for migrants in China have consistently been shown to be significantly lower than for residents when they do receive treatment $[32,103]$.

To avoid such barriers in access to HIV/AIDS services when free care is officially available, states and international agencies and donors need to formulate programs to specifically address internal migrants' needs. Crucially, cross-regional linkages need to be developed to facilitate the transition from one regional health authority's care to the next, where health care is not administered at a national level. The process of developing specialized services for internal migrants should include an assessment of the extent to which differences in treatment protocols and drug combinations across regions within a country or across health care providers within the country impede internal migrants' continuity of care. Additional programs facilitating migrants' care could include providing translators who could translate to the languages internal migrants to the region frequently speak, providing mobile outreach services or transport from areas where internal 
migrants live to health centers, educating health care providers as to migrants' particular needs and rights, or holding patient education sessions geared toward migrants.

\section{Conclusion}

Internal migration is a reality of life for millions of people, and often a pre-condition for the economic and social development on which governments, families, and communities rely. In times of financial crisis, the need to serve and support those people who have been the engine of economic growth is all the more acute. Social protection and health care systems need to keep pace with the reality of internal migration. The criticism of human rights researchers in China, that: " [t]he hukou system has always been unfair to migrants, but the economic crisis makes it downright punitive by denying many long-term migrants who have literally built the cities they live in a social welfare net when it is needed most" [16] can be generalized wherever residence-based restrictions on health services are in place. In the face of HIV and other transmissible diseases, serving internal migrants is a public health imperative. Furthermore, it is an obligation that governments have taken upon themselves under international human rights law, including through their commitment to attaining universal access to HIV prevention, treatment, care and support. In national and international efforts at system-wide change in the wake of the economic crisis, taking account of the health needs, human rights, and development goals of internal migrants will be critical to better supporting the next generation of the international economy's workers.

\section{Summary}

Worldwide, far more people migrate within their country than out of it. Internal migrants are those individuals who change residence from one civil division to another within their country of origin. Gaps in internal migrants' access to HIV/AIDS services--either as a result of official restrictions or cultural and linguistic barriers--have significant consequences: individuals are less able to access prevention, care and treatment, states are less able to realize goals of reduced HIV incidence and burden of disease, and the public health community may face the emergence of drug-resistant strains resulting from interruptions in treatment. This article describes some of the barriers to access to HIV/AIDS-related services faced by internal migrants when they move from their place of origin, highlighting three countries--China, Russia, and India--that have strict internal migration restrictions, and linguistic and cultural barriers to HIV/AIDS prevention and treatment. Given that international human rights law guarantees individuals lawfully within a territory the right to free movement within the borders of that state, a right to the highest attainable standard of health care, and the principle of non-discrimination, states have a duty to provide a core minimum of health care services including HIV prevention and treatment to internal migrants on a non-discriminatory basis. Targeted HIV prevention programs and the elimination of restrictive residence-based eligibility criteria are also necessary to ensuring internal migrants' equal rights to HIV prevention and treatment.

\section{Competing interests}

The authors declare that they have no competing interests. This research was supported by Human Rights Watch, an independent, nongovernmental organization.

\section{Authors' contributions}

Both authors wrote, edited, and approved the final manuscript.

\section{References}

I. International Organization for Migration: Internal migration and development: a global perspective. 2005.

2. The World Bank: Remittances: Eastern Europe and the former Soviet Union. 2006 [http://siteresources.worldbank.org/INTECA/ Resources/257896-I 167856389505/Migration FullReport.pdf].

3. The World Bank: Averting a human crisis during the global downturn: policy options from the World Bank's human development network: conference edition. [http://siteresources.worldbank.org/ NEWS/Resources/AvertingTheHumanCrisis.pdf].

4. Guise A, Woodward D, Lee PT, De Vogli R, Tillman T, McCoy D: Engaging the health community in global economic reform. Lancet 2009, 373:987-88.

5. LaFraniere S: China puts joblessness for migrants at $\mathbf{2 0}$ million. NY Times 2009.

6. Universal Declaration of Human Rights. G.A. Res. 2I7A. U.N GAOR, 3d Sess. Ist plen. mtg. U.N. Doc A/8IO 1948.

7. International Covenant on Civil and Political Rights. G.A. Res. 2200A (XXI). 2 I U.N. GAOR Supp. No. 16 at 52. U.N. Doc. A/63 I6 I 966.

8. Human Rights Committee: General comment 27: freedom of movement. 1999.

9. International convention on the elimination of all forms of racial discrimination. G.A. Res. $2106(X X)$, Annex. 20 U.N. GAOR Supp. No. 14 at 47. U.N. Doc. A/60I 41966.

10. Li X, Zhang L, Fang X, Chen X, Lin D, Mathur A, Stanton B: Stigmatization experienced by rural-to-urban migrant workers in China: findings from a qualitative study. World Health Popul 2007, 9:29-43.

II. Hong Y, Li X, Stanton B, Fang X, Lin D, Wang J, Mao R, Yang H: Expressions of HIV-related stigma among rural-to-urban migrants in China. AIDS Patient Care STDs 2008, 22:823-31.

12. Joint United Nations Programme on HIVIAIDS (UNAIDS): Migrants and HIV: 'far away from home' club. 2009 [http:// www.unaids.org/en/KnowledgeCentre/Resources/FeatureStories/ archive/2009/2009050I Vien Nam.asp].

13. National Bureau of Statistics of China [http://
] www.stats.gov.cn/english/]

14. International Labor Office: Equality at work: tackling the challenges: global report under the follow-up of the ILO declaration on fundamental principles and rights at work. International Labor Conference 2007 [http://www.ilo.org/wcmspgroups/public/---dgreports/dcomm/---webdev/documents/publication/wcms 082607.pdf].

15. Shaokang Z, Zhenwei S, Blas E: Economic transition and maternal health care for internal migrants in Shanghai, China. Health Policy Plan 2002, I 7(Suppl I):47-48.

16. Human Rights Watch: Press Release: China: Congress should end migrant discrimination. 2009 [http://www.hrw.org/en/news/ 2009/03/03/china-congress-should-end-migrant-discrimination].

17. Congressional-Executive Committee on China: China's household registration system: sustained reform needed to protect China's rural migrants. [http://www.cecc.gov/pages/news/ hukou.php]. 
18. Amnesty International: People's Republic of China: internal migrants: discrimination and abuse: the human cost of an economic 'miracle'. ASA I 7/008/2007 2007.

19. Human Rights Watch: China - One year of my blood: exploitation of migrant construction workers in Beijing. Human Rights Watch 2008, 20(3(C)):

20. Human Rights Watch: China/North Korea - Denied status, denied education: children of North Korean women in China. Human Rights Watch 2008 [http://hrw.org/reports/2008/ northkorea0408/northkorea0408webwcover.pdf].

21. Hu X, Cook S, Salazar MA: Internal migration and health in China. Lancet 2008, 372:1717.

22. Human Rights Watch: Locked doors: the human rights of people living with HIVIAIDS in China. Human Rights Watch 2003, I 5(7(C)): I-95.

23. Amnesty International USA: Press Release: China's crackdown on activists intensified because of Beijing Olympics, says Amnesty International. 2008 [http://www.amnestyusa.org/docu ment.php?id=ENGUSA2008040100 l \&lang=e].

24. Ransom I: Recyclers scrapped from Beijing ahead of Olympics. NY Times 2008.

25. Wong FY, Huang ZJ, He N, Smith BD, Ding Y, Fu C, Young D: HIV risks among gay- and non-gay-identified migrant money boys in Shanghai, China. AIDS Care 2008, 20:170-80.

26. Lin $D$, Fang $Z$, Li $X, X u$ J, Liu H: HIVIAIDS prevention and intervention in Chinese migrants. China J AIDS/STD 2005, I I:I58-60.

27. Hong Y, Stanton B, Li X, Yang H, Lin D, Fang X, Wang J, Mao R: Rural-to-urban migrants and the HIV epidemic in China. AIDS Behar 2006, 10:421-30.

28. UNAIDS, Global Business Coalition on HIVIAIDS, Tuberculosis and Malaria, China HIVIAIDS Media Partnership: AIDS-related knowledge, attitudes, behavior, and practices: a survey of 6 Chinese cities. 2008 [http://www.unaids.org.cn/uploadfiles/ 20080925I50557.pdf].

29. The UN Theme Group on HIVIAIDS in China: 2001 update of the AIDS situation and needs assessment report. 2002.

30. Kaufman J: Infectious disease challenges in China. In China's Capacity to Manage Infectious Diseases Edited by: Freeman CW, Lu X. Washington, D.C.: Center for Strategic and International Studies; 2009:3-16

31. World Health Organization, UNAIDS, and UNICEF: Epidemiological fact sheet on HIV and AIDS: core data on epidemiology and response: China. 2008.

32. Vail J: Managing infectious diseases among China's migrant populations. In China's Capacity to Manage Infectious Diseases Edited by: Freeman CW, Lu X. Washington, D.C.: Center for Strategic and International Studies; 2009:17-25.

33. Wong E: Factories shut, China workers are suffering. NY Times 2008 [http://www.nytimes.com/2008// ///4/worlasi /4china.html?page wanted=|\&sq=pearl\%20river\%20delta\%20crisis\&st=cse\&scp $=3$ ].

34. Yang X, Xia G: Gender, migration, risky sex, and HIV infection in China. Stud Fam Plann 2006, 37:24I-50.

35. Road map charted for universal health care. China Daily 2009.

36. Schaible DS: Life in Russia's "closed city": Moscow's movement restrictions and the rule of law. NY Univ Law Rev 200I, 76:344-73.

37. Eke S: Moscow offers 'migrant amnesty'. BBC News 2008 [http:l Inews.bbc.co.uk/2/hi/europe/727/445.stm].

38. International Organization for Migration: World migration 2008: Europe. [http://www.iom.int/jahia/webdav/shared/shared/mainsite/ media/docs/wmr/regional overviews/ro europe.pdf]

39. Russian Federation: Code of administrative offences. 200। [http://www.russian-offences-code.com/Sectionll/Chapter I9.html].

40. Leviyeva $E$ : The changing face of Russian democracy: racism and xenophobia in Russia--foreign students under attack in Russia and US. Rutgers Race and the Law Rev 2005, 7:229-88.

4I. Human Rights Watch: Russian Federation - Moscow: open season, closed city. 1997.

42. The constitution of the Russian Federation 1993 [http:// www.constitution.ru/en/l0003000-0I.htm]

43. U.S. Committee for Refugees and Immigrants: World refugee survey 2008: Russian Federation. 2008 [http://www.refugees.org/ countryreports.aspx?id=2164].

44. Russian Federation: Federal law on the prevention of the spread in the Russian Federation of diseases caused by the human immunodeficiency virus (HIV-infection). 1995 [http:// www.ilo.org/public/english/protection/trav/aids/laws/russianlaw.pdf].

45. AVERT: HIVIAIDS in Russia, Eastern Europe \& Central Asia. [http://www.avert.org/aids-russia.htm].

46. Transatlantic Partners Against AIDS: Federal law "On prevention of spreading in the Russian Federation of disease caused by the human immunodeficiency virus (HIV infection)": background, content, and perspectives. 2004 [http://hivpolicy.net/ upload/File/RelatedFiles/publication/209/839.pdf]

47. World Health Organization, UNAIDS, and UNICEF: Epidemiological fact sheet on HIV and AIDS: core data on epidemiology and response: Russian Federation. 2008 [http://www.who.int/ globalatlas/predefinedReports/EFS2008/full/EFS2008 RU.pdf].

48. D'Adesky AC: HIV erupts in Russia: part 2: Putin's silence. Gully 2003 [http://www.thegully.com/essays/russia/ 031215 russia HIV AIDS 2.html].

49. Moscow Department of Health Care [http://www.mos
[ gorzdrav.ru/]

50. Human Rights Watch: Positively abandoned: stigma and discrimination against HIV-positive mothers and their children in Russia. Human Rights Watch 2005, I 7(4(D)): I-43.

5I. ITAR-TASS: Half of all crimes in Moscow committed by migrants says police chief. BBC Worldwide Monitoring 2009.

52. The people crunch: global migration and the downturn. Economist 2009.

53. AVERT: Who is affected by HIVIAIDS in India? [http:// www.avert.org/hiv-india.htm]

54. Migrants carry HIV home in poor Indian state. Reuters 2006

55. Halli SS, Blanchard J, Satihal DG, Moses S: Migration and HIV transmission in rural south India: an ethnographic study. Cult Health Sex 2007, 9:85-94.

56. The World Bank: HIVIAIDS in India: the state of the epidemic. 2007 [http://siteresources.worldbank.org/INTSAREGTOPHIVAIDS/ Resources/HIV-AIDS-brief-Aug07-IN.pdf].

57. National AIDS Control Organization, Government of India: UNGASS country progress report 2008: India.

58. Akabiwa NJ: Migration and HIVIAIDS in rural areas: the case of 'de-urbanization' in parts of Zambia. 2007.

59. World Health Organization (WHO), Joint United Nations Programme on HIVIAIDS (UNAIDS), and UNICEF: Epidemiological fact sheet on HIV and AIDS: core data on epidemiology and response: India: 2008 update. 2008.

60. Joint United Nations Programme on HIVIAIDS (UNAIDS) Programme Coordinating Board: Migration and HIVIAIDS: second ad hoc thematic meeting provisional agenda item 5. 2008.

61. AVERT: Overview of HIV and AIDS in India. [http:// www.avert.org/aidsindia.htm].

62. Rogaly B, Coppard D, Rafique A, Rana K, Sengupta A, Biswas J: Seasonal migration and welfare/illfare in eastern India: a social analysis. J Dev Stud 2002, 38:89-I I 4.

63. Bird K, Deshingkar P: Circular migration in India: policy brief no. 4. ODI World Development Report 2009 [http://www.odi.org.uk/ resources/download/2506.pdf].

64. Actionaid India: "We are citizens too," say India's marginalized \begin{tabular}{l} 
groups. $2007 \quad$ [http://www.actionaid.org/kenyal \\
\hline
\end{tabular} index.aspx?PagelD=\%20363I].

65. International Labour Organization Subregional Office for South Asia: India: state government sponsored community health insurance scheme. [http://www.ilo.org/public/english/region/asro/bang kok/events/sis/download/paper16.pdf]

66. Nair P: No aid for HIV positive 'outsiders'. Gomantak Times Weekender 2006 [http://community.worldaidscampaign.net/show thread.php?t=20I].

67. Bajoria J: Financial crisis may worsen poverty in China, India. Council on Foreign Relations 2008 [http://www.cfr.org/publication/ $178 \mid 2 /]$.

68. Pimple M: Global financial crisis: implications for India's development. End Poverty 2015 Millennium Campaign [http:/l] www.endpoverty2015.org/files/Global\%20Financial\%20Crisis\%20\%20Implications\%20for\%20India's\%20Development.pdf].

69. Subbarao D: Impact of the global financial crisis on India collateral damage and response. 2009 [http://www.rbi.org.in/ Scripts/BS SpeechesView.aspx?ld=4|0].

70. International Covenant on Economic, Social and Cultural Rights. G.A. Res. 2200A (XXI). 2 I U.N. GAOR Supp. No. 16 at 49. U.N. Doc. A/6316. 993 U.N.T.S. 31966. 
71. UN Committee on Economic, Social and Cultural Rights: General comment no. 14: the right to the highest attainable standard of health. 2000.

72. Office of the United Nations High Commissioner for Human Rights and World Health Organization: The right to health: fact sheet no. 3 I. 2008

73. Cholewinski R: Economic and social rights of refugees and asylum seekers in Europe. Georgetown Immig Law J 2000, 14:709-55.

74. Convention on the Rights of the Child. G.A. Res. 44/25, Annex. 44 U.N. GAOR Supp. No. 49 at 167. U.N. Doc. A/44/49 1989.

75. Convention on the Elimination of All Forms of Discrimination Against Women. G.A. Res. 34//80, 34. U.N. GAOR Supp. No. 46 at 193. U.N. Doc. A/34/46 I98I.

76. International Convention on the Protection of the Rights of All Migrant Workers and Members of their Families. G.A. Res. 45/I58, Annex. 45 U.N. GAOR Supp. No. 49(A) at 262. U.N. Doc. A/45/ 491990.

77. International Convention on the Protection and Promotion of the Rights and Dignity of Persons with Disabilities. G.A. Res. 6//106, Annex I. U.N. GAOR, 6/st Sess., Supp. No. 49, at 65. U.N. Doc A/61/49 2006.

78. UN Declaration of Commitment on HIVIAIDS. G.A. Res. S-26/ 2. U.N. Doc. A/RES/S-26/2 200I.

79. Human Rights Committee: General comment 18: non-discrimination. 1994.

80. Committee on the Rights of the Child: General comment No. 3: HIVIAIDS and the rights of the children. CRC/GC/2003/32003.

8I. Amon JJ, Todrys KW: Fear of foreigners: HIV-related restrictions on entry, stay and residence. J Int AIDS Soc 2008, I I:

82. Schiller NG, Crystal S, Lewellen D: Risky business: the cultural construction of AIDS risk groups. Soc Sci Med 1994, 38: I337-46.

83. Amon J, Todrys K: Access to antiretroviral treatment for migrant populations in the global south. Sur J 2009, I 0: I55-76.

84. Human Rights Watch: Discrimination, denial, and deportation: human rights abuses affecting migrants living with HIV. Human Rights Watch 2009: I-25. I-56432-490-7

85. Human Rights Watch, Deutsche AIDS Hilfe, European AIDS Treatment Group, African HIV Policy Network: Returned to risk: deportation of HIV-positive migrants. Human Rights Watch 2009: I-27.

86. Human Rights Watch: A grim year of the ox. 2009 [http:// www.hrw.org/en/news/2009/01/27/grim-year-ox]

87. World Health Organization Country Office for India: Accelerating the scale-up of HIVIAIDS treatment and care. [http:/l www.whoindia.org/en/Section3/Section I 25 I433.htm].

88. World Health Organization: WHO discussion paper: the practice of charging user fees at the point of service delivery for HIVIAIDS treatment and care. 2005 [http://www.who.int/hiv/ pub/advocacy/promotingfreeaccess.pdf].

89. Human Rights Watch: A high price to pay: detention of poor patients in hospitals. Human Rights Watch 2006, I 8(8(A)): I-79.

90. Human Rights Watch: No bright future: government failures, human rights abuses and squandered progress in the fight against AIDS in Zimbabwe. Human Rights Watch 2006, 18(5(A)): I-74.

91. Amon J], Kasambala T: Structural barriers and human rights related to HIV prevention and treatment in Zimbabwe. Glob Public Health 2009: I- 17.

92. Kippenberg J, Sahokwasama JB, Amon J]: Detention of insolvent patients in Burundian hospitals. Health Policy Plan 2008, 23:14-23.

93. Souteyrand YP, Collard V, Moatti JP, Grubb I, Guerma T: Free care at point of service delivery: a key component for reaching universal access to HIVIAIDS treatment in developing countries. AIDS 2008, 22:s|6|-68.

94. Tam F: Migrant workers likely to visit illegal clinics despite deaths. South China Morning Post 2009.

95. Amon JJ: Dangerous medicines: unproven AIDS cures and counterfeit antiretroviral drugs. Global Health 2008, 4:

96. Biswas R: The hidden costs of treatment. 2009 [http://www.hiv aidsonline.in/index.php/Treatment/the-hidden-costs-of-treatnt.html].

97. World Health Organization: WHO model list of essential medicines. 2007.

98. Report of the Special Rapporteur on the right of everyone to the enjoyment of the highest attainable standard of physical and mental health. U.N. Doc. A/6//338 2006.
99. Human Rights Watch: Russia - "Are you happy to cheat us?" exploitation of migrant construction workers in Russia. Human Rights Watch 2009 [http://www.hrw.org/sites/default/files/ reports/russia0209 webwcover.pdf].

100. Heldal E, Kuyvenhoven JV, Wares F, Migliori GB, Ditiu L, Fernandez de la Hoz K, Garcia D: Diagnosis and treatment of tuberculosis in undocumented migrants in low- or intermediate-incidence countries. Int J Tuberc Lung Dis 2008, I 2:878-88.

10I. World Health Organization: WHO report 2009: global tuberculosis control: India. [http://www.who.int/tb/publications/ global report/2009/pdf/ind.pdf].

102. Lu X: The challenge of tuberculosis control in China. In China's Capacity to Manage Infectious Diseases Edited by: Freeman CW, Lu X. Washington, D.C.: Center for Strategic and International Studies; 2009:26-32.

103. China Equi-TB Programme: TB control in China. 2006.
Publish with Bio Med Central and every scientist can read your work free of charge

"BioMed Central will be the most significant development for disseminating the results of biomedical research in our lifetime. "

Sir Paul Nurse, Cancer Research UK

Your research papers will be:

- available free of charge to the entire biomedical community

- peer reviewed and published immediately upon acceptance

- cited in PubMed and archived on PubMed Central

- yours - you keep the copyright
BioMedcentral 